\title{
Analysis of the Effect Product Quality, Trustworthiness, Convenience, Perceptions of Usefulness and Price on Purchase Intention During the Covid Pandemic 19
}

\author{
Gregorius Widiyanto1) \\ gregorius.widiyanto@ubd.ac.id \\ FX. Pujo Wibowo \\ pudjo.wibowo@ubd.ac.id2) \\ 1) 2) University of Buddhi Dharma
}

\begin{abstract}
This study aims to examine the effect of product quality on buying interest during the Covid 19 pandemic, trust in buying interest during the Covid 19 pandemic, ease of purchase interest during the Covid 19 pandemic, perceived usefulness of purchase interest during the Covid 19 pandemic, and prices on buying interest.

The sampling method used was purposive side method, obtained a sample of 140 respondents. Methods of data analysis are using multiple linear regression, $T$ test and $F$ test for data processing using SPSS version 25.

The results of this study prove that trust and convenience have a significant effect on buying interest during the Covid 19 pandemic, while product quality, perceived usefulness and price have no effect on purchase intention during the Covid 19 pandemic. While simultaneously have a significant effect on purchase interest in the future.
\end{abstract}

Keywords: Product quality, trustworthiness, convenience, perceived usefulness, price on purchase Intention 


\section{Research Background}

The Covid-19 pandemic has changed many people's habits in various activities, including shopping for policies from several countries to carry out social restrictions to minimize the spread of the Corona Covid-19 virus, many have chosen to shop online. As a result, there are no face-to-face transactions like what generally happened before the pandemic, on the other hand, this situation also encourages the acceleration of the digital economy. Where the sellers inevitably have to switch to new strategies to follow the development of people's consumption patterns towards digital.

The research released at the end of January 2020 stated that the number of internet users in Indonesia had reached 175.4 million people, while the total population of Indonesia was around 272.1 million. Compared to 2019, the number of internet users in Indonesia has increased by around 17 percent or 25 million users.

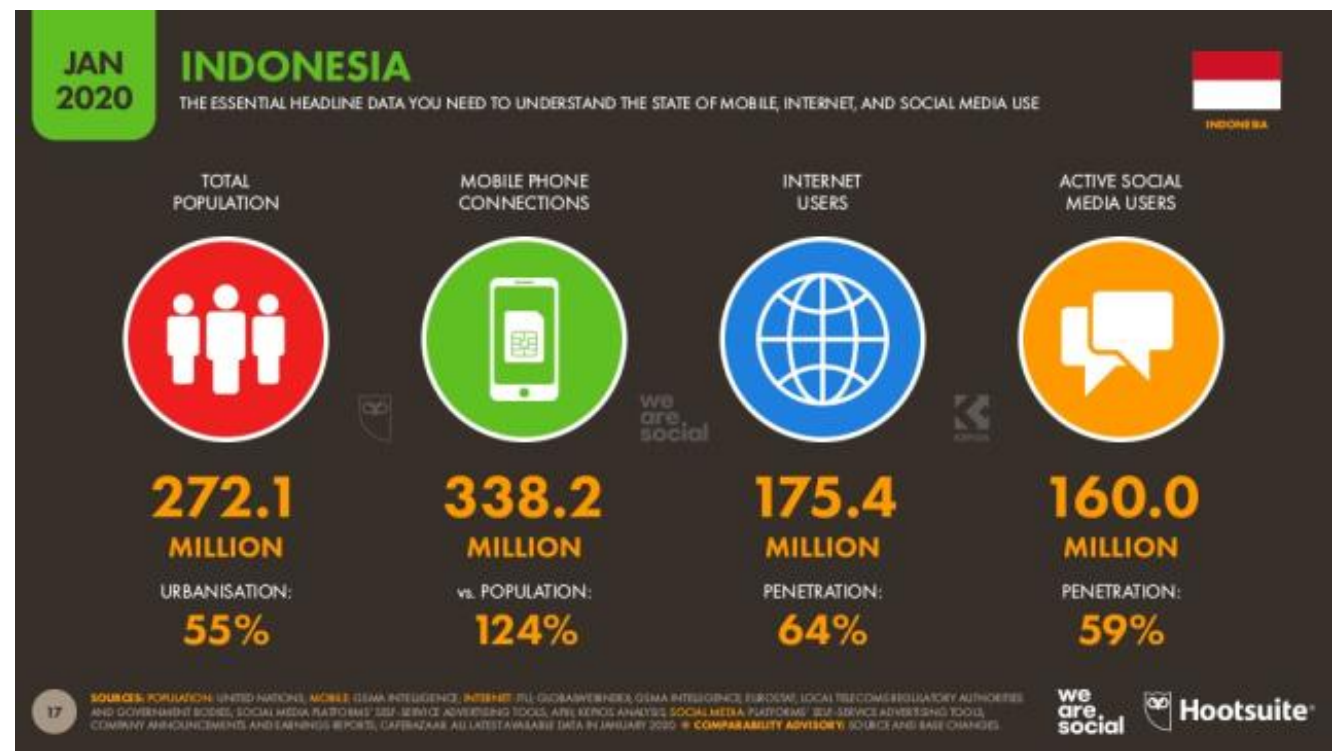

Sources: https:/ / kumparan.com/kumparantech

Indonesia also has other achievements in the number of social media users. Still from the same research, the number of social media users in Indonesia has reached 160 million, an increase of 8.1 percent or 12 million users compared to last year. That way, the penetration of social media use in Indonesia has reached 59 percent of the total population.

The E-commerce Map of Indonesia ranks the big e-commerce players based on the average website visitors in each quarter, app ranking, social media followers, and number of employees. 


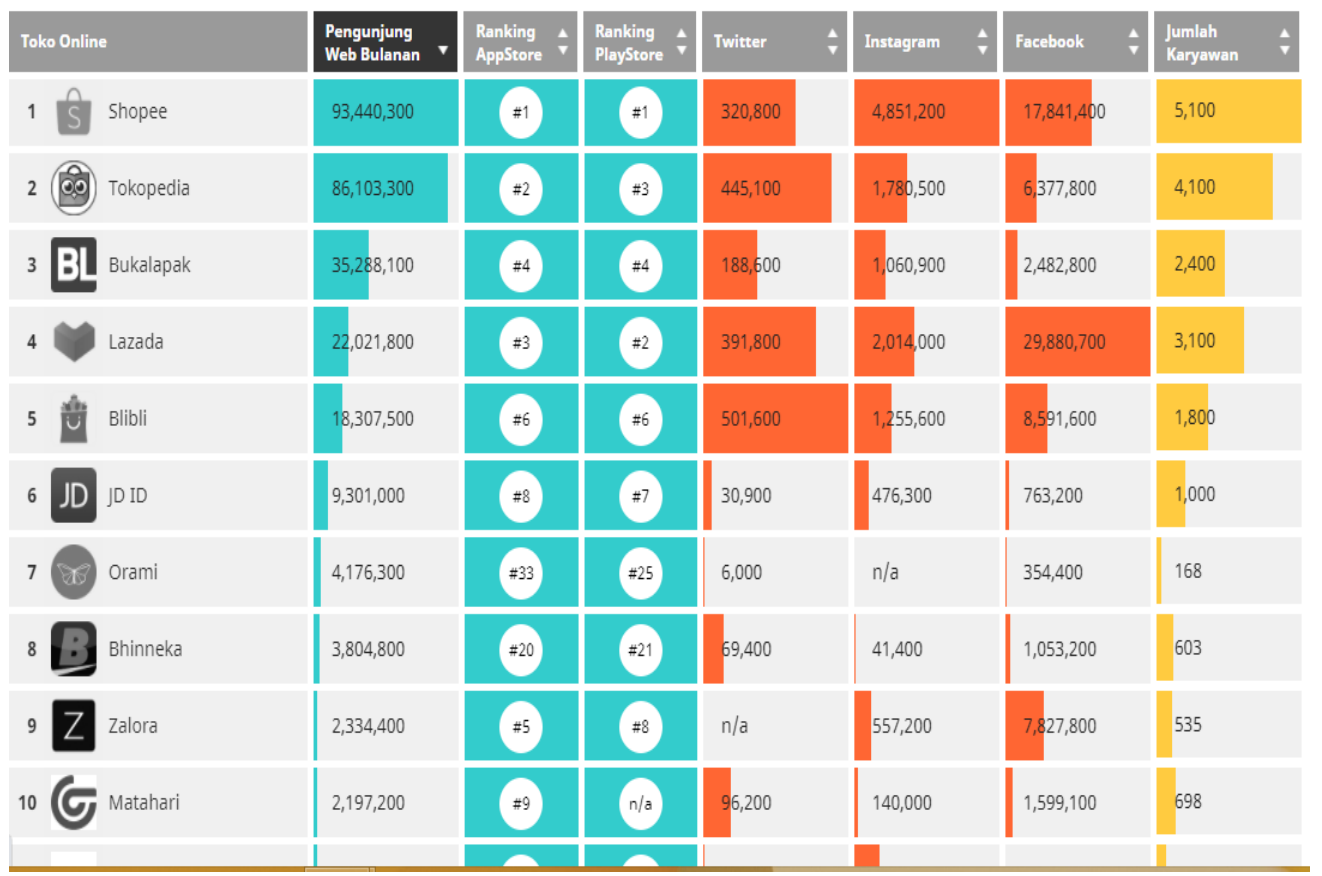

Sources: https://iprice.co.id/insights/mapofecommerce/

From the information above, it is known that the development of e-commerce in Indonesia is very helpful for the national economy; this can be seen from the visitors of each e-commerce. With many visitors, it means that people's buying interest through online shopping is very high.

Based on the phenomena described above, it appears that the increasing number of online shopping transactions is directly proportional to the increase in the number of internet users. This statement is in accordance with the results of research conducted by Liao and Cheung (2001). The results of this study explain that the increasing the number of internet users, the more happy internet users are shopping online.

Research conducted by Rositasari (2016) entitled "The Influence of Trust, Perceived Risk, Perceived Ease, and Perceptions of Benefits on Purchasing Attitudes of Fashion Products through the Online Shop (Study on Facebook Users in Indonesia)". The results of these studies indicate that the ease of use variable has a positive and significant effect on consumer attitudes in purchasing a product through an online shop. Sidharta and Sidh (2014) in their research entitled "Measurement of Perceptions of Benefits and Perceptions of Ease of Attitudes and Their Impact on Reuse of Online Shopping in E-commerce". The results of these studies indicate that the ease of use variable affects consumer attitudes in online shopping. Ulumiyah (2016) conducted research on "Analysis of the Effect of WOM, Pengalaman Belanja Online Persepsi Kemudahan dan Persepsi Risiko terhadap Minat Belanja Online Melalui Sikap Belanja Online (Studi pada Online Store Elzatta Hijab)". Online Shopping Experience regarding Ease of Perception and Risk Perception of Online Shopping Interest through Online Shopping Attitude (Study on Elzatta Hijab Online Store) ". In this study, the variable indicates that the ease of use variable has a positive and significant effect on consumer attitudes in online shopping. 


\section{Formulation of the problem}

Based on the background and problem identification described above, the problems in this study can be formulated as follows:

1. Does product quality affect purchase interest during the Covid 19 pandemic?

2. Does trust affect on buying interest during the Covid 19 pandemic?

3. Does convenience affect on buying interest during the Covid 19 pandemic?

4. Does perceived usefulness affect buying interest during the Covid 19 pandemic?

5. Does the price affect on buying interest during the Covid 19 pandemic?

6. Do product quality, trustworthiness, convenience, perceived usefulness and price jointly affect buying interest during the Covid 19 pandemic?

\section{Research purposes}

Based on the problem formulation above, the objectives of this study are to identify:

1. To find out whether product quality affects buying interest during the Covid 19 pandemic?

2. To find out whether trust has an effect on buying interest during the Covid 19 pandemic?

3. To find out whether convenience affects purchase interest during the Covid 19 pandemic?

4. To find out whether perceived usefulness has an effect on buying interest during the Covid 19 pandemic?

5. To find out whether prices have an effect on buying interest during the Covid 19 pandemic?

6. To find out whether product quality, trustworthiness, convenience, perceived usefulness and price jointly affect buying interest during the Covid 19 pandemic?

\section{RESEARCH METHODS}

\section{Population and Sample Research}

\section{Population}

Population is a generalization area consisting of objects or subjects that have certain qualities and characteristics that are determined by the researcher to study and then draw conclusions (Sugiyono, 2008). In this study, the population is internet users in 7 (seventh) semester students of Buddhi Dharma University.

\section{Sample}

According to Sugiyono (2018: 81) the sample is part of the number and characteristics of the population. In sample selection, there is a sampling technique to determine which sample will be used in the study; therefore the sample in this study is 140 .

\section{Data collection technique}

Data collection techniques in this study using a questionnaire. The questionnaire is a data collection technique that is carried out by giving a set of written questions to respondents to be answered (Sugiyono, 2008). The questionnaire was used to obtain respondent data regarding product quality, trustworthiness, convenience, perceived usefulness, price, and purchase interest during the Covid 19 pandemic.

\section{Operational definition}


The operational definition is a description of the definitions and indicators of the variable variables used in research. The operational definition in this study is:

\section{Independent Variable}

Independent variables are variables that affect the dependent variable, either positively or negatively. The independent variables in this study include:

\section{a. product quality}

According to Kotler and Keller (2012), product quality is:

"The ability of an item to provide results or performance that is appropriate and even exceeds what the customer wants"

Product quality is one of the keys competition between business people and is offered to customers. customers always want to get quality products according to the price paid, even though there are some people who think that, there is quality there is a price. If this can be done by the company, then the company will still be able to satisfy its customers and be able to increase the number of customers.

b. Trust

According to Mowen and Minor in Donni Juni (2017: 116) Trust is all knowledge possessed by consumers and all conclusions made by consumers about objects, attributes and benefits.

From the above definition it can be concluded that belief is an expectation held by an individual or a group when words, promises, oral or written statements from an individual or other group can be realized.

\section{c. Convenience}

The definition of convenience according to Roger in the research journal Yuli Harwani (2017) states that the perception of ease of use is as follows:

"Ease of use is the extent to which innovative technology is considered not difficult to learn, understand, and operate. This concept includes the clarity of the purpose of using information technology (IT) and the ease of using the system for the purpose of the user."

\section{d. Perceived usefulness}

According to Venkatesh and Davis (2000), perceived usefulness is a measure to determine a person's level of confidence in the use of a system to improve performance. If someone believes about information systems and is useful, then the system will be used and vice versa. In addition, the level of consumer confidence is also obtained from the level of consumer confidence in being able to obtain convenience or simplification of financial transactions in everyday life.

e. Price

The definition of price according to Kotler (2010: 314) is: "Price is the amount of money charged for a product or service or the amount of value that consumers exchange for benefits due to owning or using the product or service".

\section{Dependent variable}


The dependent variable according to Sugiyono (2009) is a variable that is influenced or becomes a result because of the independent variables. The dependent variable in this study is buying interest during the COVID-19 pandemic.

\section{RESEARCH RESULTS AND DISCUSSION \\ Multiple linear regression}

The following are the results of research testing using a test tool in the form of SPSS V.25 in the form of a regression coefficient. This figure will illustrate the regression equation at the numbers shown. And to prove the influence or not between each independent variable on the dependent variable.

\begin{tabular}{|c|c|c|c|c|c|c|c|c|}
\hline \multicolumn{9}{|c|}{ Coefficients $^{a}$} \\
\hline \multirow[b]{2}{*}{ Mode } & & \multicolumn{2}{|c|}{ Unstandardized Coefficients } & \multirow{2}{*}{$\begin{array}{c}\begin{array}{c}\text { Standardized } \\
\text { Coefficients }\end{array} \\
\text { Beta }\end{array}$} & \multirow[b]{2}{*}{$t$} & \multirow[b]{2}{*}{ Sig. } & \multicolumn{2}{|c|}{ Collinearity Statistics } \\
\hline & & $B$ & Std. Error & & & & Tolerance & VIF \\
\hline \multirow[t]{6}{*}{1} & (Constant) & 5.347 & 1.833 & & 2.918 & .004 & & \\
\hline & Kualitas Produk & .059 & .118 & .054 & .502 & .616 & .418 & 2.395 \\
\hline & Kepercayaan & .270 & .105 & .284 & 2.579 & .011 & .390 & 2.561 \\
\hline & Kemudahan & .283 & .121 & .253 & 2.337 & .021 & .404 & 2.477 \\
\hline & Persepsi Kegunaan & -.003 & .123 & -.003 & -.024 & .981 & .360 & 2.776 \\
\hline & Harga & .097 & .101 & .101 & .956 & .341 & .424 & 2.358 \\
\hline
\end{tabular}

a. Dependent Variable: Minat Beli di Masa Pandemi Covid 19

Based on the above, the researcher will describe the five independent variables, namely product quality (X1), trust (X2), convenience (X3), perceived usefulness (X4), and price (X5) into the regression equation. The regression equation above can be explained as follows:

$\mathrm{Y}=\mathrm{a}+\beta 1 \mathrm{X} 1+\beta 2 \mathrm{X} 2+\beta 3 \mathrm{X3}+\beta 4 \mathrm{X} 4+\beta 5 \mathrm{X} 5+\mathrm{e}$

Explanation:

$\mathrm{Y}$ : Purchase interest during the Covid pandemic 19

a : Constant

$\beta$ : Regression Coefficient

X1 : Product quality

$\mathrm{X} 2$ : Trust

$\mathrm{X} 3$ : Convenience

X4 : Perceived Usability

X5 : Price

e : error

$Y=5.347+0.059 X_{1}+0,270 X_{2}+0,283 X_{3}-0,003 X_{4}+0,097 X_{5}+e$

The regression equation above can be explained as follows:

1. A constant of 5,347 means that if the independent variables, namely product quality (X1), trust (X2), convenience (X3), perceived usefulness (X4), and price (X5) are zero, the purchase intention during the Covid pandemic is 19 in value fixed at 5,356.

2. The regression coefficient of the Product Quality variable (X1) is 0.059 with a positive sign which means that if there is an increase in the Product quality variable (X1) by 
one unit assuming other variables are constant, then the amount of buying interest during the Covid 19 pandemic (Y) will increase by 0.059 units.

3. The regression coefficient of the Product Quality variable (X2) is 0.270 with a positive sign which means that if there is an increase in the Product quality variable (X2) by one unit assuming other variables are constant, then the amount of buying interest in the Covid 19 pandemic (Y) will increase by 0.270 units.

4. The regression coefficient of the Product Quality variable (X3) is 0.283 with a positive sign which means that if there is an increase in the Product quality variable (X3) by one unit assuming other variables are constant, then the amount of buying interest during the Covid 19 pandemic (Y) will increase by 0.283 units.

5. The regression coefficient of the Product Quality variable (X4) is -0.003 with a positive sign which means that if there is an increase in the Product quality variable (X4) by one unit assuming other variables are constant, then the amount of buying interest during the Covid 19 pandemic (Y) will decrease. by 0.003 units.

6. The product quality variable regression coefficient (X5) is 0.097 with a positive sign which means that if there is an increase in the Product quality variable (X5) by one unit assuming other variables are constant, then the amount of buying interest during the Covid 19 pandemic (Y) will increase by 0.097 units. .

\section{Coefficient of Determination (R2)}

The coefficient of determination (R2) is used to measure the ability of the model to explain the variation in the dependent variable. The coefficient of determination is between zero and one. If the research results are closer to zero, the ability of the independent variables to explain the variation of the variables is still limited. But if it is close to number 1 , it means that the independent variables provide almost all the information needed to predict the variation in the dependent variable.

\section{Model Summary ${ }^{\mathrm{b}}$}

\begin{tabular}{|l|l|r|r|r|}
\hline Model & $\mathrm{R}$ & R Square & \multicolumn{1}{c|}{$\begin{array}{c}\text { Adjusted R } \\
\text { Square }\end{array}$} & $\begin{array}{c}\text { Std. Error of } \\
\text { the Estimate }\end{array}$ \\
\hline 1 & $.604^{\mathrm{a}}$ & .364 & .341 & 3.13723 \\
\hline
\end{tabular}

a. Predictors: (Constant), Harga, Kemudahan, Kualitas Produk, Kepercayaan, Persepsi Kegunaan

b. Dependent Variable: Minat Beli di Masa Pandemi Covid 19

Based on the table above, the coefficient of determination (Adjusted R Square) is 0.341 . These results indicate that the five independent variables in this study only have $34.1 \%$ influence on the dependent variable, the remaining $65.9 \%$ is influenced by other factors that have not been examined in this study.

\section{Simultaneous Significance Test (Test Statistic F)}

The $\mathrm{F}$ test is used to determine whether all the independent variables included in the regression model have a joint influence on the dependent variable. 
ANOVA $^{\mathrm{a}}$

\begin{tabular}{|c|c|c|c|c|c|c|}
\hline & & $\begin{array}{l}\text { Sum of } \\
\text { Squares }\end{array}$ & df & Mean Square & $\mathrm{F}$ & Sig. \\
\hline \multirow[t]{3}{*}{1} & Regression & 756.114 & 5 & 151.223 & 15.365 & $.000^{b}$ \\
\hline & Residual & 1318.857 & 134 & 9.842 & & \\
\hline & Total & 2074.971 & 139 & & & \\
\hline
\end{tabular}

In the

a. Dependent Variable: Minat Beli di Masa Pandemi Covid 19

table

b. Predictors: (Constant), Harga, Kemudahan, Kualitas Produk, Kepercayaan, Persepsi Kegunaan

above, it

can be seen that the probability or significance of the ANOVA calculation is used to test the regression model. With the provision that the probability number is smaller than 0.05 , which means that simultaneously product quality, trustworthiness, convenience, perceived usefulness and price together have an effect on asking to buy during the Covid 19 pandemic.

\section{T statistical test (t test)}

The $t$ statistical test is used to show how far the influence of one explanatory (independent) variable individually in explaining the variation in the dependent variable. The criteria for testing the hypothesis using the $t$ statistical test is if the significant value $t<0.05$ means that there is a significant influence between the independent variable and the dependent variable, conversely if the significant value $t>$ 0.05 means that there is no significant effect between the independent variable and the dependent variable. .

\begin{tabular}{|c|c|c|c|c|c|c|c|c|}
\hline \multirow[b]{2}{*}{ Mode } & & \multicolumn{2}{|c|}{ Unstandardized Coefficients } & \multirow{2}{*}{$\begin{array}{c}\text { Standardized } \\
\text { Coefficients }\end{array}$} & \multirow[b]{2}{*}{$t$} & \multirow[b]{2}{*}{ Sig. } & \multicolumn{2}{|c|}{ Collinearity Statistics } \\
\hline & & $B$ & Std. Error & & & & Tolerance & VIF \\
\hline \multirow[t]{6}{*}{1} & (Constant) & 5.347 & 1.833 & & 2.918 & .004 & & \\
\hline & Kualitas Produk & .059 & .118 & .054 & .502 & .616 & .418 & 2.395 \\
\hline & Kepercayaan & .270 & .105 & .284 & 2.579 & .011 & .390 & 2.561 \\
\hline & Kemudahan & .283 & .121 & .253 & 2.337 & .021 & .404 & 2.477 \\
\hline & Persepsi Kegunaan & -.003 & .123 & -.003 & -.024 & .981 & .360 & 2.776 \\
\hline & Harga & .097 & .101 & .101 & .956 & .341 & .424 & 2.358 \\
\hline
\end{tabular}

a. Dependent Variable: Minat Beli di Masa Pandemi Covid 19

Based on the table above, the results of the $t$ test for each variable are as follows:

a. Product Quality (X1) has a t value of $0.502<t$ table 1.656 with a sig value of $0.616>$ 0.05 , meaning that product quality has no effect on buying interest during the Covid 19 pandemic.

b. Trust (X2) has a $t$ value of $2.579>t$ table 1.656 with a sig value of $0.011<0.05$, meaning that trust has an effect on buying interest during the Covid 19 pandemic.

c. Convenience $(\mathrm{X} 3)$ has a $t$ count value of $2.337<t$ table 1.656 with a sig value of $0.021<0.05$, meaning that ease has an effect on buying interest during the Covid 19 pandemic. 
d. Perception of usefulness (X4) has a t-count value of $-0.024<t$ table 1.656 with a sig value of $0.616<0.05$, meaning that perceived usefulness has no effect on buying interest during the Covid pandemic 19.

e. Price (X5) has a $t$ value of $0.956<t$ table 1.656 with a sig value of $0.341<0.05$, meaning that price has no effect on buying interest during the Covid 19 pandemic.

\section{CONCLUSION}

1. Product Quality $(X 1)$ has a sig value of $0.616>0.05$, meaning that product quality has no effect on buying interest during the Covid 19 pandemic.

2. Trust $(X 2)$ has a sig value of $0.011<0.05$, which means that trust has an effect on buying interest during the Covid 19 pandemic.

3. Convenience $(X 3)$ has a sig value of $0.021<0.05$, meaning that ease has an effect on buying interest during the Covid 19 pandemic.

4. Perceived Usefulness (X4) has a sig value of $0.616<0.05$, meaning that perceived usefulness has no effect on buying interest during the Covid pandemic 19.

5. Price (X5) has a sig value of $0.341<0.05$, meaning that price has no effect on buying interest during the Covid 19 pandemic.

6. Product quality, Trustworthiness, Convenience, Perception of Usefulness and Price together have an effect on buying interest during the COVID-19 pandemic.

\section{REFERENCES}

Agustinus Mulyadi, Dian Eka, Welly Nailis. Pengaruh kepercayaan, kemudahan dan kualitas informs terhadap keputusan pembelian di toko online Lazada. Jurnal Ilmiah Manajemen Bisnis Dan Terapan Tahun XV No 2, Oktober 2018.

Aimsyah, Z. 2003. Manajemen Sistem Informasi. Jakarta: PT. Gramedia Pustaka. Alviolita, Luh Kusuma Nusarika. Pengaruh Persepsi Harga, Kepercayaan, dan Orientasi Belanja Terhadap Niat Beli Secara Online (Studi pada Produk Fashion Online di

Kota Denpasar). E-Jurnal Manajemen Unud, Vol. 4, No. 8, 2015 : 2380-2406

Anggraeni, Penia dan Putu Nina Madiawati. 2016. Pengaruh Kepercayaan dan Kualitas Informasi Terhadap Keputusan Pembelian Secara Online pada Situs Traveloka.com. E-Proceeding of Management: Vol. 3 (2) : 1880.

Cahya, Anandya Hardiawan. 2013. Pengaruh Kepercayaan, Kemudahan, dan Kualitas Informasi terhadap Keputusan Pembelian Secara Online di Tokobagus.com. Universitas Diponegoro.

Daft, Richard L. 2007. Management. Jakarta: Salemba Empat.

Ainun Budi Aji. Pengaruh Keamanan, Kemudahan, dan Resiko Kerja terhadap Keputusan Pembelian Secara Online di Tokopedia.com. Universitas Negeri Yogyakarta.

Jogiyanto. 2007. Sistem Informasi Keperilakuan. Yogyakarta : Andi Yogyakarta.

Kotler, Philip dan Gary Armstrong. 2008. Prinsip-Prinsip Pemasaran. Jakarta: Erlangga.

McLeod, Raymond Jr dan George P. Schell. 2008. Sistem Informasi Manajemen. Jakarta : Salemba Empat. 
Moch Suhir, Imam Suryadi, Riadi. Pengarug Persepsi Resiko, Kemudahan dan Manfaat Terhadap Keputusan Pembelian Secara Online (Survey terhadap situs website www.kaktus.co.id) Jurnal Administrasi Bisnis (JAB) | Vol. 8 No. 1 Februari 2014|

Putra, Andy Mahkota dan Imam Suyadi. Pengaruh Kepercayaan dan Kenyamanan Terhadap Keputusan Pembelian Online (Studi Pada Pelanggan Website Ride Inc). Jurnal Administrasi Bisnis, Vol. 8, No. 2, Maret 2014.

Rr. Selli Nisrina Faradila, Harry Soesanto. Analisis Pengaruh Persepsi Kemudahan penggunaan, Persepsi Manfaat Terhadap Minat Beli dengan Kepercayaan Sebagai Variabel Intervening.(Studi kaus pada Pengunjung Toko Online berrybenka.con di Kalangan Mahasiswa Universitas Diponogoro). Jurnal Studi Manajemen \& Organisasi 13 (2016).

Siahaan, Pangeran. 2016. Pengaruh Kepercayaan, Kemudahan, dan Harga terhadap Keputusan Pembelian Online di Tokopedia.com. Universitas Sriwijaya. Sugiyono. 2008. Metode Penelitian Bisnis. Bandung: Alfabeta. 